\title{
Concomitant surgical treatment of a chondrosarcoma of the chest wall and a desmoid tumor of the gastrointestinal tract
}

\author{
Andrzej Sadowski ${ }^{1}$, Iwona Chruścicka ${ }^{2}$, Piotr Rak ${ }^{2}$, Anna Ptach ${ }^{3}$, Daniel Maliszewski ${ }^{2}$, Rafał Pęksa ${ }^{4}$, \\ Ireneusz Haponiuk ${ }^{5}$, Jacek Zieliński ${ }^{2}$ \\ ${ }^{1}$ Department of General Surgery, Tczew Hospitals JSC, Tczew, Poland \\ ${ }^{2}$ Chair and Clinic of Oncological Surgery, Medical University of Gdansk, Gdansk, Poland \\ ${ }^{3}$ Emergency Department, Municipal Hospital in Gdynia, Gdynia, Poland \\ ${ }^{4}$ Chair and Department of Pathomorphology, Medical University of Gdansk, Gdansk, Poland \\ ${ }^{5}$ Department of Cardiac Surgery of the Copernicus Pomeranian Trauma Center in Gdańsk, Gdansk, Poland \\ Kardiochirurgia i Torakochirurgia Polska 2015; 12 (2): 166-169
}

\begin{abstract}
The co-existence of a chondrosarcoma of the chest wall and a desmoid tumor in the gastrointestinal tract is rare. In both Polish and global literature, cases of chest wall chondrosarcomas are presented in the form of case reports. Desmoids of the gastrointestinal tract are more common; notwithstanding, their incidence in Europe is estimated at approximately 2 cases per 1 million inhabitants per year.

We present the case of a 62-year-old female patient who suffered from both a chest wall chondrosarcoma and a desmoid tumor of the intestine; both neoplasms were operated on simultaneously.

The former tumor was located in the region of the right costal margin, whereas the latter was located in the mesojejunum. The surgery was performed with two independent surgical incisions. The postoperative period was uneventful. The case is noteworthy in view of the extremely rare synchronous occurrence of the described tumors and due to the fact that any such operation requires an individualized surgical approach. Key words: chondrosarcoma, desmoid tumor, surgical treatment.
\end{abstract}

\section{Introduction}

Concomitant development of a chondrosarcoma of the chest wall and a desmoid tumor of the gastrointestinal tract is a rare phenomenon. In both Polish and global literature, cases of chest wall chondrosarcomas are presented in the form of case reports. In terms of location, this cancer is most often found in the pectoral girdle, pelvis, and ribs, and

\section{Streszczenie}

Jednoczesne występowanie chrzęstniakomięsaka ściany klatki piersiowej oraz desmoidu przewodu pokarmowego należy do rzadkości. W świecie i w Polsce chrzęstniakomięsaki ściany klatki piersiowej są prezentowane w postaci opisów kazuistycznych. Znacznie częściej opisywane są desmoidy przewodu pokarmowego, jednak częstość zachorowań w Europie oceniana jest na poziomie ok. 2 przypadków na milion mieszkańców rocznie. Celem pracy jest przedstawienie chorej, u której stwierdzono występowanie chrzęstniakomięsaka ściany klatki piersiowej oraz desmoidu jelita cienkiego, które leczono operacyjnie jednocześnie. U 62-letniej chorej rozpoznano: guza położonego w okolicy prawego łuku żebrowego oraz drugiego, zlokalizowanego w krezce jelita czczego. Zabieg chirurgiczny przeprowadzono z dwóch niezależnych dostępów operacyjnych. Przebieg pooperacyjny był niepowikłany.

Prezentowany opis przypadku jest ciekawy z uwagi na wyjątkowo rzadkie występowanie synchroniczne obu guzów oraz na fakt, iż każda tego typu operacja wymaga indywidualizacji postępowania chirurgicznego.

Słowa kluczowe: chondrosarkoma, desmoid, leczenie chirurgiczne.

less frequently in other bones [1, 2]. Desmoids of the gastrointestinal tract are much more common; notwithstanding, their incidence in Europe is estimated at approximately 2 cases per $1 \mathrm{~m}$ inhabitants per year.

Desmoid tumors of the gastrointestinal tract develop primarily in patients between the ages of 40 and 70, but have sometimes been observed in younger individuals

Address for correspondence: Jacek Zieliński, Chair and Clinic of Oncological Surgery, Medical University of Gdansk, Gdansk, 17 Smoluchowskiego St., 80-214 Gdansk, Poland, phone: +48 5834931 90, e-mail: jaziel@gumed.edu.pl 
and children $[3,4]$. However, no case has previously been described in which a chest wall chondrosarcoma was concomitant with a desmoid tumor of the gastrointestinal tract.

The aim of this report is to present the case of a female patient diagnosed with the presence of a chest wall chondrosarcoma and an intestinal desmoid tumor that were treated with concomitant surgery.

\section{Case study}

The 62-year-old patient was diagnosed with the presence of two tumors based on computed tomography. One tumor was located in the vicinity of the right costal margin, while the other was in the mesojejunum, near the ligament of Treitz, encompassing a fragment of the wall of the first jejunal loop. Both tumors qualified for surgical treatment. The only symptom presented by the patient was a small deformation on the right side of the chest wall; the lesions were not painful. The patient's medical history included surgical treatment conducted 28 years prior due to a desmoid tumor of the rectus abdominis muscle and uterine myomas.

Physical examination demonstrated the chest tumor to be exophytic, $10 \mathrm{~cm}$ in diameter, cohesive, and skincolored; the tumor did not move in relation to the base and was not painful. Physical examination of the abdomen demonstrated it to be soft, without peritoneal signs or palpable pathological resistance. The lymph nodes were not enlarged, and the performed laboratory investigation revealed no abnormalities.

\section{Procedure}

The procedure was conducted under general anesthesia, using two independent surgical access points (under the right costal margin and from a median incision of the abdomen) enabling good visualization of both tumors (Fig. 1). In intraoperative evaluation, the largest dimension of the tumor on the right costal margin was $15 \mathrm{~cm}$; there were no signs of infiltration of the liver or other structures of the abdominal cavity. The other tumor was located in the mesojejunum near the ligament of Treitz; it adhered closely to the splenic flexure of the colon, but without infiltration. Palpation did not reveal metastases to the liver, the parietal or visceral peritoneum, or other abdominal organs (Fig. 2).

After the assessment of the abdominal organs, a decision was made to resect both tumors. During the resection of the chest wall tumor, substantial parts of ribs 6,7 , and 8 were excised in order to achieve oncological radicality. The rib stumps were repaired with coaptation sutures. Additionally, an infiltrated fragment of the diaphragm was excised, and the resulting defect was repaired with polypropylene mesh; active drainage was applied to the pleural cavity (Fig. 3A).

The next stage of the procedure consisted in the resection of the intestinal tumor. After the incision of the visceral peritoneum, the mesenteric vessels were uncovered, showing no infiltration by the tumor mass. The tumor was excised together with the surrounding jejunum (Fig. 3B). The intestinal stumps were closed with linear staplers; after duodenal mobilization, a two-layer side-to-side anastomosis was performed. The postoperative course was uneventful.

The patient was discharged on the $20^{\text {th }}$ postoperative day. Follow-up was conducted on an outpatient basis. The evaluation of histopathological slides and oncological consultation showed that the patient did not require complementary treatment. During 2 years of follow-up, no signs of recurrence were observed with regard to the chest wall or the abdominal organs. Postoperative histopathological
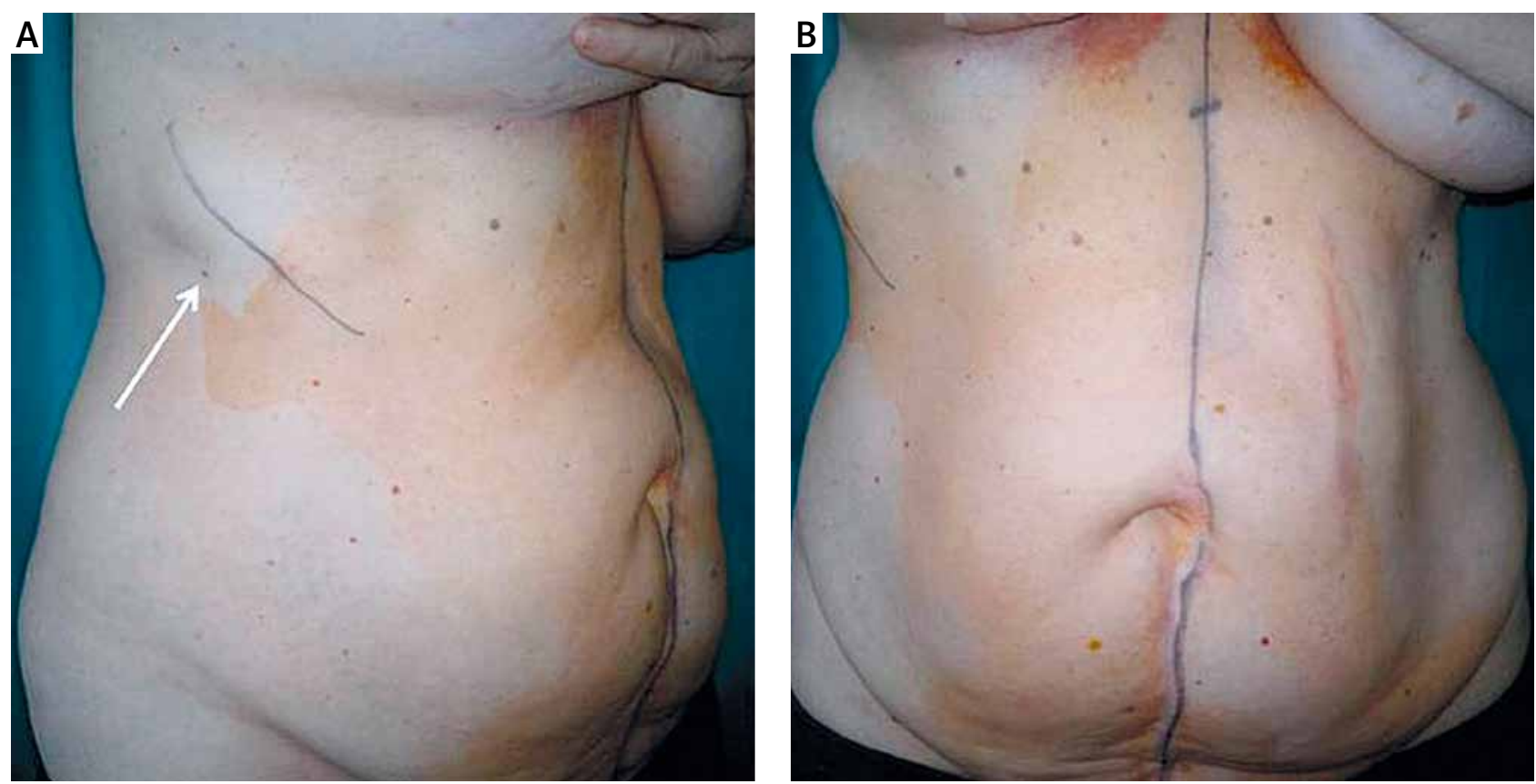

Fig. 1. The planned lines of surgical incision (the arrow shows the chest wall tumor) 

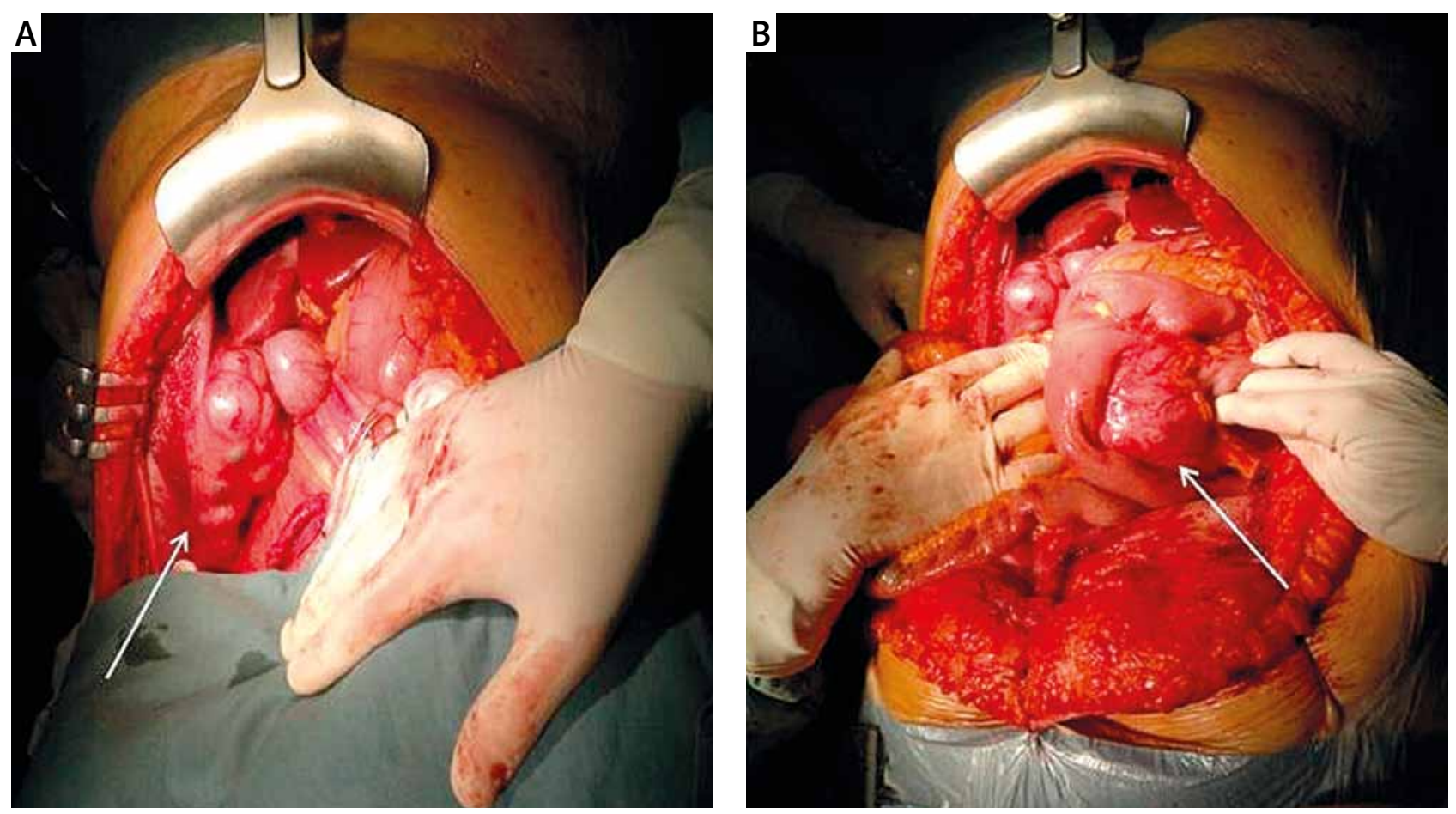

Fig. 2. Intraoperative image of the tumors (A - chondrosarcoma, B - desmoid; as indicated by the arrows)
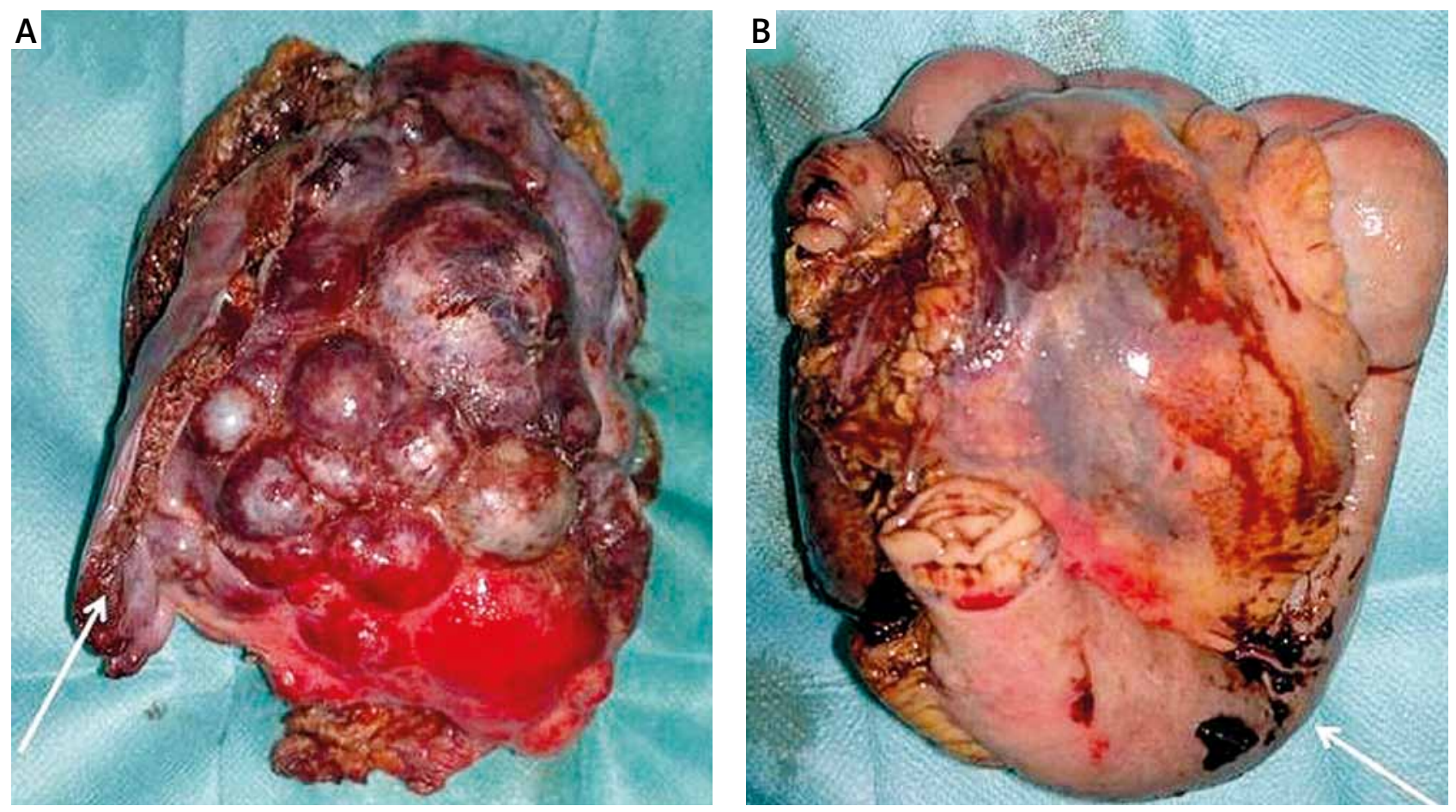

Fig. 3. Postoperative macroscopic images of the tumors (A - chondrosarcoma: the arrow indicates a fragment of the chest wall, $\mathbf{B}$ - desmoid: the arrow indicates the fragment of the jejunum that was in direct contact with the tumor)

examination of the costal margin tumor confirmed the diagnosis of chondrosarcoma, and the tumor in the mesojejunum was confirmed to be a desmoid tumor (Fig. 4).

\section{Discussion}

Chondrosarcoma is a malignant cancer producing cartilaginous tissue. It is the second most common skeletal neoplasm after osteosarcoma. Chondrosarcoma most often develops between the ages of 50 and 70 . It occurs slightly more often in men than in women $(1 / 5: 1)$. It may develop in any bone, but is most often found in the pelvis, chest bones, and the scapulas $[4,5]$.

Our patient suffered from a chest wall sarcoma of cartilaginous origin (chondrosarcoma), which constitutes 15\% 

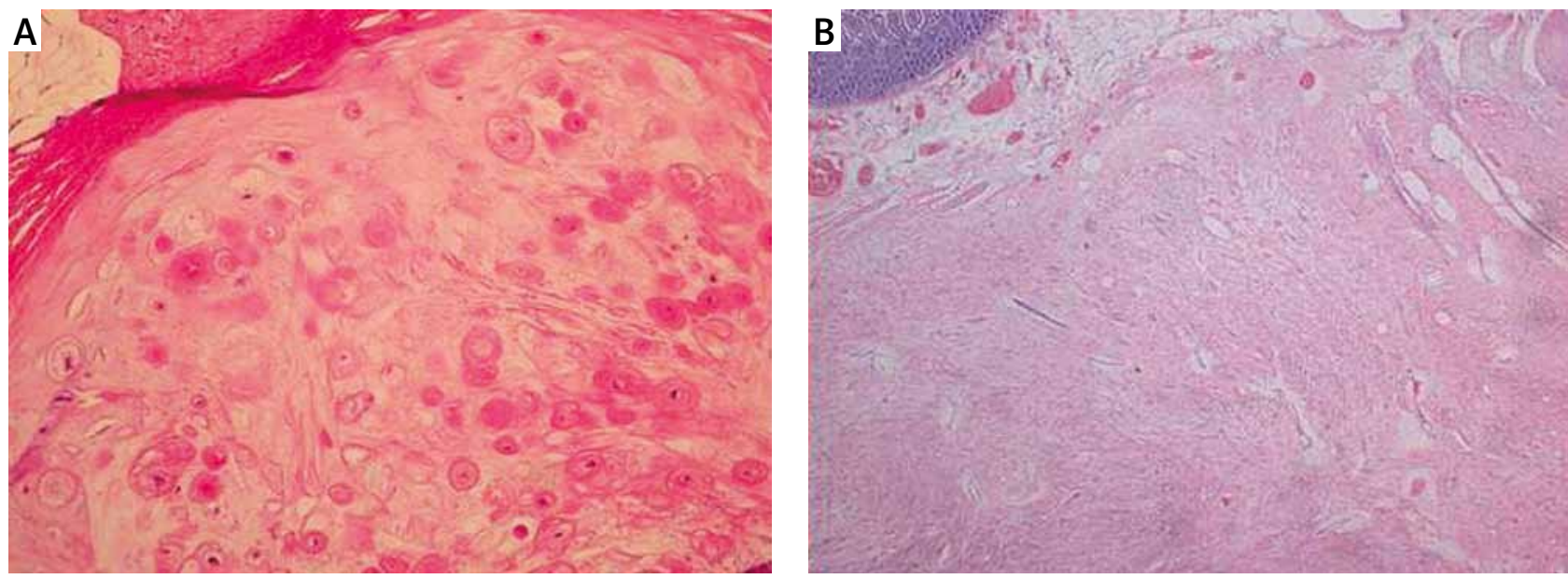

Fig. 4. Microscopic images of the tumors (A - chondrosarcoma, B - desmoid)

of all reported cases of such neoplasms. The goal of treating chondrosarcomas is their radical resection $[6,7]$. It is important for patients with these tumors to be treated in experienced medical centers, as only interdisciplinary management may result in achieving the best outcomes [8-10]. Frequently, non-standard management is required as well as the participation of both oncological and thoracic surgeons. In our case, it was necessary to reconstruct the chest wall and the rib stumps using coaptation sutures and to repair the diaphragmatic defect with polypropylene mesh.

Desmoids are a rare type of tumor originating from the cells of the fascia or musculotendinous tissue. Although lack of metastasis is characteristic, desmoids often infiltrate the surrounding tissue: if the resection is not radical, this results in local recurrence [4].

According to the clinical classification of desmoids developed by Church et al., the present case was evaluated as stage 3. In accordance with the suggestions included in the classification, our case could have been treated conservatively, using pharmacotherapy: non-steroidal antiinflammatory drugs, tamoxifen, raloxifene, vinblastine, or methotrexate [3]. However, due to the concurrent presence of the chest wall tumor, surgery was considered to be a more optimal treatment option.

In the case of abdominal tumors, radical surgery is particularly difficult. Desmoids are associated with a high risk of local recurrence $[3,4]$. In the present case, radical surgery was performed as the tumor had not infiltrated the surrounding tissues and vessels. As there are no clear standards on the subject, the management of desmoid tumors should always be tailored to individual patients, and the employed treatment should consider the patient's quality of life. Apart from physical examination and imaging examinations, intraoperative assessment of the tumor is the most important factor for deciding whether the tumor can be resected [8-10]. In the present case, radical surgery alone was considered to be the most appropriate treatment option for our patient.
We decided to present this report because the subject literature features no case in which an intra-abdominal desmoid tumor is concomitant with a chest wall chondrosarcoma. The lack of infiltration as well as the size and location of the tumors at the time of diagnosis enabled the performance of a radical surgical treatment. No uniform algorithm describes patient management in cases in which both these neoplasms develop concurrently. The presented management scheme was tailored to the circumstances, and the uneventful postoperative course confirms that the therapeutic decision was correct.

\section{Dislocure}

Authors report no conflict of interest.

\section{References}

1. Widhe B, Bauer HC. A population-based Scandinavian Sarcoma Group study of 106 patients. J Thor Cardiovasc Surg 2009; 137: 610-614.

2. Zielińska-Kaźmierska B, Grodecka J, Neskoromna A. Chondrosarcoma szczęki - opis przypadku. Contemp Oncol (Pozn) 2005; 9: 75-77.

3. Church J, Berk T, Boman BM, Guillem J, Lynch C, Lynch P, Rodriguez-Bigas M, Rusin L, Weber T. Staging intra-abdominal desmoid tumors in familial adenomatous polyposis: a search for a uniform approach to a troubling disease. Dis Colon Rectum 2005; 48: 1528-1534

4. Lahat G, Nachmany I, Itzkowitz E, Abu-Abeid S, Barazovsky E, Merimsky O, Klauzner J. Surgery for Sporadic Abdominal Desmoid Tumor: Is Low/No Recurrence an Achievable Goal? Isr Med Assoc J 2009; 11: 398-402.

5. Szmidt J, Gruca Z, Krawczyk M, Kużdżał J, Lampe P. Podstawy chirurgii. Medycyna Praktyczna, Kraków 2009; 827.

6. Zieliński J, Jaworski R, Pawlaczyk R, Świerblewski M, Kabata P, Jaśkiewicz J, Rogowski J. Simultaneous surgery for critical aortic stenosis and gastric cancer: a case report. World J Gastroenterol 2010; 16: 1161-1164.

7. Zieliński J, Kruszewski WJ, Jaworski R, Haponiuk I, Irga N, Zygoń J, Kopacz A, Jaśkiewicz J. Rare oesophageal tumours: experience of one centre. Eur Surg 2012; 44: 361-365.

8. Jaworski R, Zieliński J, Gross M, Kopacz A. Olbrzymi guz stromalny przewodu pokarmowego: opis przypadku. Nowotwory J Oncol 2008; 58: 59-61.

9. Zieliński J, Jaworski R, Kabata P, Kruszewski WJ, Jaśkiewicz J. Gastric cancer in Poland: clinical characteristics and results of surgery. Dig Surg 2010; 27: 409-416.

10. Jaworski R, Bollschweiler E, Holscher AH, Monig SP, Skokowski J, Zieliński J, Świerblewski M, Kopacz A, Jaśkiewicz J. Prognostic relevance of demographics and surgical practice for patients with gastric cancer in two centers: in Poland versus Germany. Gastric Cancer 2011; 14: 234-241. 